\title{
Long-term lead elimination from plasma and whole blood after poisoning
}

\author{
Gerda Rentschler $\cdot$ K. Broberg $\cdot$ T. Lundh $•$ \\ S. Skerfving
}

Received: 29 November 2010/Accepted: 14 June 2011/Published online: 24 June 2011

(C) The Author(s) 2011. This article is published with open access at Springerlink.com

\begin{abstract}
Objective Blood lead ( $\mathrm{B}-\mathrm{Pb})$, one of the most used toxicological biomarker all kind, has serious limitations. Thus, the objective is to evaluate whether plasma lead $(\mathrm{P}-\mathrm{Pb})$ is more adequate.

Methods A long-term follow-up study of five cases of lead poisoning. $\mathrm{P}-\mathrm{Pb}$ was analysed by inductively coupled plasma mass spectrometry. Kinetics after end of exposure was modelled.

Results $\mathrm{P}-\mathrm{Pb}$ at severe poisoning was about $20 \mu \mathrm{g} / \mathrm{L}$; haematological effects at about $5 \mu \mathrm{g} / \mathrm{L}$. Biological halftime of $\mathrm{P}-\mathrm{Pb}$ was about 1 month; $\mathrm{B}-\mathrm{Pb}$ decay was much slower.

Conclusion $\mathrm{P}-\mathrm{Pb}$ is a valuable biomarker of exposure to and risk, particularly at high exposure.
\end{abstract}

Keywords Human - Urine $\cdot \mathrm{Pb} \cdot$ Kinetics $\cdot$ Modelling · Risk

\section{Introduction}

The lead $(\mathrm{Pb})$ concentration in whole blood $(\mathrm{B}-\mathrm{Pb})$ is probably — next to ethanol in blood-the most widely used biomarker for assessment of toxic exposure and risk. However, it has clear limitations, in particular because

G. Rentschler $(\bowtie) \cdot$ K. Broberg $\cdot$ T. Lundh $\cdot$ S. Skerfving Division of Occupational and Environmental Medicine, Lund University, SE-221 85 Lund, Sweden

e-mail: Gerda.Rentschler@med.lu.se there is saturation with increasing exposure, in particular at B-Pbs $>700 \mu \mathrm{g} / \mathrm{L}$ (Bergdahl et al. 1999), and because $\mathrm{Pb}$ induces anaemia (Skerfving and Bergdahl 2007), which will make the use of $\mathrm{B}-\mathrm{Pb}$ problematic, because $\mathrm{Pb}$ is mainly present in erythrocytes, the volume of which will decrease. $\mathrm{Pb}$ in plasma $(\mathrm{P}-\mathrm{Pb})$ or serum is an attractive alternative, which would avoid these problems (Schütz et al. 1996; Costa de Almeida et al. 2010; Montenegro et al. 2006; Hirata et al. 1995). The concentrations are very low, but the developments in analytical technique now allow adequate determination. However, $\mathrm{P}-\mathrm{Pb}$ has up to now been used only occasionally.

There are indications that the toxicokinetics of $\mathrm{Pb}$ are affected by genetic polymorphism in the enzyme $\delta$-aminolevulinic acid dehydratase (ALAD), which is the main binding site for $\mathrm{Pb}$ in erythrocytes, and inhibition of which is at least partly responsible for the anaemic effect of $\mathrm{Pb}$ (Skerfving and Bergdahl 2007).

In spite of centuries of preventive attempts, $\mathrm{Pb}$ is still a major health problem. It induces clinical poisoning in occupational settings, but sometimes also by other exposures (Skerfving and Bergdahl 2007).

The aim of this study was to scrutinise the usability of $\mathrm{P}-\mathrm{Pb}$ as a biomarker in cases of clinical $\mathrm{Pb}$ poisoning.

\section{Subjects and methods}

\section{Cases}

We evaluated data from five cases of clinical $\mathrm{Pb}$ poisoning, four non-occupational and one occupational (Table 1). They had been exposed to $\mathrm{Pb}$ for 1 month-12 years. The intakes of $\mathrm{Pb}$ were estimated by self-reported consumption of tablets or drink, and the measured contents of $\mathrm{Pb}$ in 


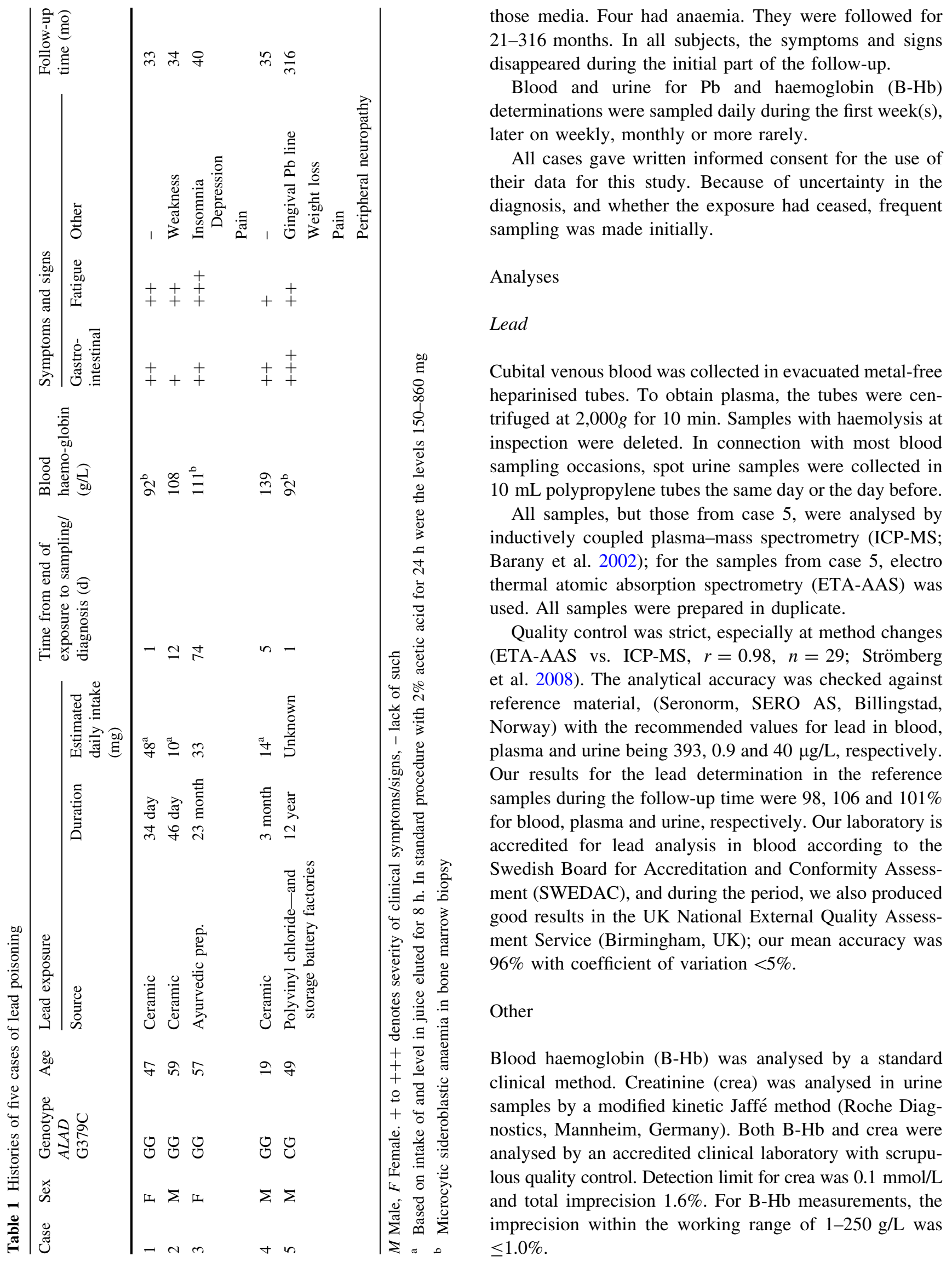


Toxicokinetic modelling

Non-linear regression analysis was performed with SPSS version 15.0, according to Eq. (1). The first exponential term describes the fast elimination phase, the second one, the slow elimination of $\mathrm{Pb}$.

$C_{\mathrm{Pb}}(t)=C_{1} * \mathrm{e}^{\left(-R_{1} * t\right)}+C_{2} * \mathrm{e}^{(-0.000146 * t)}$

$C_{\mathrm{Pb}}(t)$, lead concentration at a given time $(\mu \mathrm{g} / \mathrm{L}), t$, time (days), $C_{1}$, constant (concentration of the fast phase at $t=0$ ), $C_{2}$, constant (concentration of slow phase at $t=0$ ), $R_{1}$, elimination constant of phase $1\left(\right.$ days $\left.^{-1}\right)$.

The follow-up time was not sufficient to calculate the half-time in the slow phase. Nilsson et al. (1991) found it to be 13 years in a long-term study of $\mathrm{Pb}$ workers. Therefore, that value was used. The sum of $C_{1}$ and $C_{2}$ describes the modelled $\mathrm{Pb}$ content at the end of exposure $(t=0)$. The half-time of $\mathrm{Pb}$ in the fast phase has been calculated according to Eq. (2).

$T_{1 / 2}=\ln 2 / R_{1}$

For three cases, there were sufficient data to describe the relationship between $\mathrm{B}-\mathrm{Hb}$ and $\mathrm{P}-\mathrm{Pb}$ after end of exposure. Inspection of the curves (Fig. 4) indicated that one component did not give a satisfactory fit. Regression lines were calculated on the left and right sides of the division line $(x=5 \mu \mathrm{g}-\mathrm{Pb} / \mathrm{L})$, and statistical significance of the difference between the pairs of slopes was examined. After that the threshold between the two components was calculated as the crossing point of the two lines.

\section{Genotyping}

DNA was isolated from whole blood by minicolumn purification (E.Z.N.A DNA extraction kit, Omega Bio-Tek, Norcross, GA, USA) and diluted to a concentration of $5 \mathrm{ng} / \mu \mathrm{L}$. The $A L A D$ G379C polymorphism (Asn59Lys, rs1800435) was genotyped by Taqman allelic discrimination assay (ABI 7000 instrument, Applied Biosystems, Foster City, CA, USA), using the following primers and probes for $A L A D$ : primers forward: $5^{\prime}$-TGC CTT CCT TCA ACC CCT CTA-3' and reverse: $5^{\prime}-\mathrm{CCA}$ AGG GCC TCA GCA TCT C-3'; MGB-probes: ALAD-G: 5'-Fam-TGT GAA GCG GCT GG-3' and $A L A D-C$ : 5'-Vic-TGT GAA CCG GCT GG-3'. The total volume of the PCR was $25 \mu \mathrm{L}$. Primers were added to a final concentration of $0.05 \mu \mathrm{M}$, probes to $0.9 \mu \mathrm{M}$ in an $80 \%$ concentrated TaqMan Universal PCR Master Mix (Applied Biosystems, Foster City, CA, USA). The PCR samples were incubated at $50^{\circ} \mathrm{C}$ for $2 \mathrm{~min}$ and at $95^{\circ} \mathrm{C}$ for $10 \mathrm{~min}$. The samples underwent 40 cycles of $15 \mathrm{~s}$ at $95^{\circ} \mathrm{C}$ and $1 \mathrm{~min}$ at $60^{\circ} \mathrm{C}$. Controls for each genotype as well as blanks were included in each run. Samples were analysed in duplicate and concordance rate was $100 \%$.

\section{Results}

The median $\mathrm{P}-\mathrm{Pb}$ at first sampling (median 5, range 1-74 days after end of exposure) was 17 (range 2-42) $\mu \mathrm{g} / \mathrm{L}$ (Fig. 1a). The modelled median value for $\mathrm{P}-\mathrm{Pb}\left(C_{1}+C_{2}\right)$ was 23 (range 3-38) $\mu \mathrm{g} / \mathrm{L}$ at time $t=0$. In Cases $1-4$, the median of $C_{2}$ was 0.65 (range $0.6-0.8$ ) $\mu \mathrm{g} / \mathrm{L}$, in Case 5 $1.6 \mu \mathrm{g} / \mathrm{L}$.

In the two-compartment model, the median biological $T_{1 / 2}$ of the fast P-Pb phase was 27 (23-69) days (Table 2).

The median $\mathrm{B}-\mathrm{Pb}$ at first sampling was $790(520-1,600)$ $\mu \mathrm{g} / \mathrm{L}$ (Fig. 1b). The modelled median value for $\mathrm{B}-\mathrm{Pb}$ $\left(C_{1}+C_{2}\right)$ was 840 (range $\left.790-1,300\right) \mu \mathrm{g} / \mathrm{L}$ at time $t=0$. In Cases $1-4$, the median of $C_{2}$ was 155 (range 83-230) $\mu \mathrm{g} / \mathrm{L}$ and in Case 5, it was $290 \mu \mathrm{g} / \mathrm{L}$.

Median $T_{1 / 2}$ for the fast $\mathrm{B}-\mathrm{Pb}$ component was 77 (58-120) days (Table 2).

The relationship between $\mathrm{B}-\mathrm{Pb}$ and $\mathrm{P}-\mathrm{Pb}$ was approximately linear at low levels (ratio about 100); at P-Pbs above about $5 \mu \mathrm{g} / \mathrm{L}$, the $\mathrm{B}-\mathrm{Pb}$ levelled off (Fig. 2). In Cases 1 and 2, the ratio at the highest P-Pbs was about 40, in Case 5, it was about 60.

There seemed to be a rectilinear relationship between $\mathrm{U}-\mathrm{Pb}$ and $\mathrm{P}-\mathrm{Pb}$; the former expressed as $\mu \mathrm{g} / \mathrm{g}$ crea was
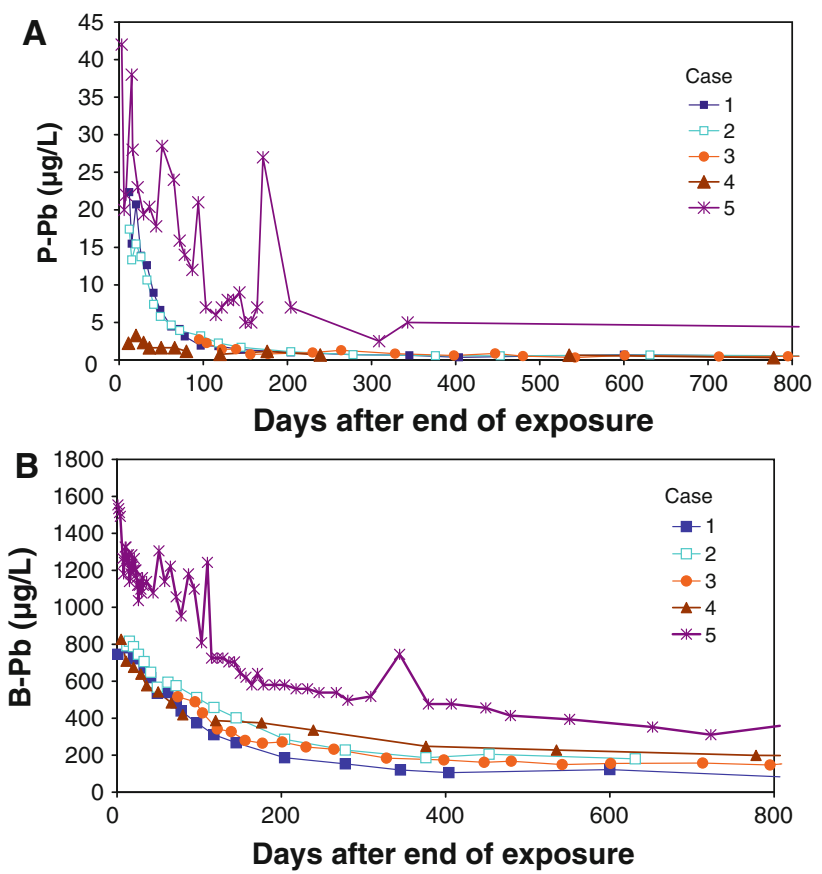

Fig. 1 Lead elimination from plasma $(\mathrm{P}-\mathrm{Pb} ; \mathbf{a})$ and whole blood $(\mathrm{B}-\mathrm{Pb} ; \mathbf{b})$ during the first 800 days after end of exposure in five cases of poisoning 
Table 2 Two-compartment modelling of lead in plasma and whole blood after end of exposure in five cases of lead poisoning

\begin{tabular}{|c|c|c|c|c|c|c|}
\hline \multirow[t]{3}{*}{ Case } & \multicolumn{3}{|l|}{ Plasma } & \multicolumn{3}{|l|}{ Whole blood } \\
\hline & \multicolumn{2}{|l|}{ First component } & \multirow{2}{*}{$\begin{array}{l}\text { Second component } \\
C_{2}(\mathrm{CI})(\mu \mathrm{g} / \mathrm{L})\end{array}$} & \multicolumn{2}{|l|}{ First component } & \multirow{2}{*}{$\begin{array}{l}\text { Second component } \\
C_{2}(\mathrm{CI})(\mu \mathrm{g} / \mathrm{L})\end{array}$} \\
\hline & $\mathrm{C}_{1}(\mathrm{CI})(\mu \mathrm{g} / \mathrm{L})$ & $T_{1 / 2}(\mathrm{CI})(\mathrm{d})$ & & $C_{1}(\mathrm{CI})(\mu \mathrm{g} / \mathrm{L})$ & $T_{1 / 2}(\mathrm{CI})(\mathrm{d})$ & \\
\hline 1 & $30(25,35)$ & $23(18,30)$ & $0.6(0.0,1.8)$ & $770(720,810)$ & $77(63,87)$ & $83(41,120)$ \\
\hline 2 & $22(19,25)$ & $27(22,35)$ & $0.8(0.0,1.6)$ & $700(660,750)$ & $87(77,120)$ & $140(120,190)$ \\
\hline 3 & $37(0,91)$ & $23(15,43)$ & $0.7(0.5,0.8)$ & $660(640,1,100)$ & $58(46,77)$ & $170(170,190)$ \\
\hline 4 & $3(2,4)$ & $46(24,350)$ & $0.6(0.3,1.1)$ & $560(500,620)$ & $63(46,87)$ & $230(190,270)$ \\
\hline 5 & $30(23,37)$ & $69(46,170)$ & $1.6(0.0,7.2)$ & $1,100(1,000,1,100)$ & $120(120,140)$ & $290(250,330)$ \\
\hline
\end{tabular}

$C_{1}$ and $C_{2}$ are concentrations at $t=0$ for the fast and slow components. $T_{1 / 2}$ half-time. $C I 95 \%$ confidence interval

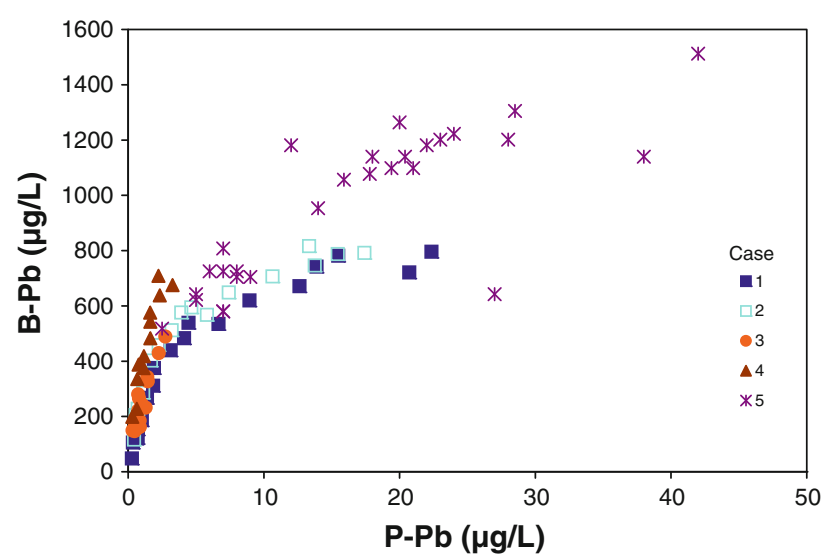

Fig. 2 Relationship between lead levels in whole blood (B-Pb) and plasma $(\mathrm{P}-\mathrm{Pb})$ in sequential samples from five cases of poisoning

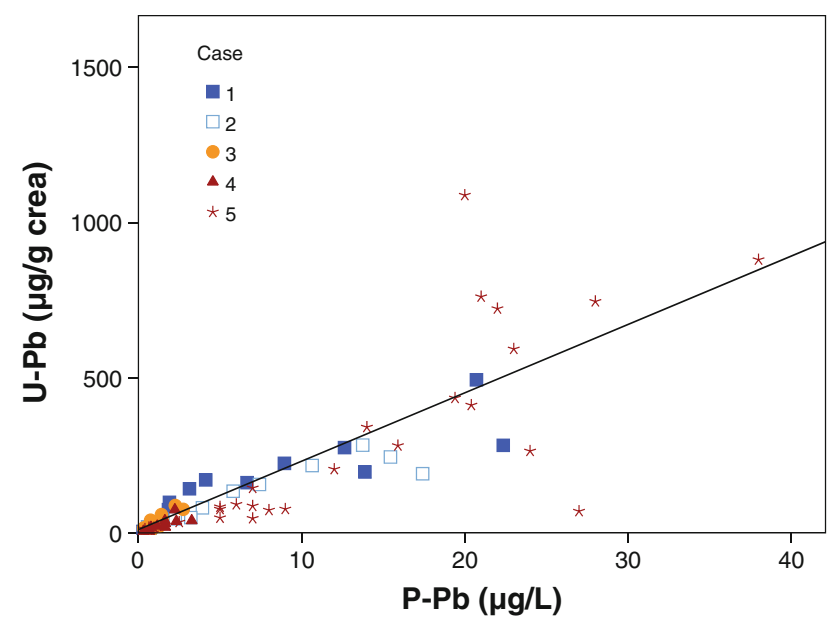

Fig. 3 Relationship between lead levels in urine $(\mathrm{U}-\mathrm{Pb})$ and plasma $(\mathrm{P}-\mathrm{Pb})$ in sequential samples from five cases of poisoning. The association between $\mathrm{U}-\mathrm{Pb}$ and $\mathrm{P}-\mathrm{Pb}$ follows the equation $\mathrm{U}-\mathrm{Pb}=$ $12+22 * \mathrm{P}-\mathrm{Pb}$

22 times higher than the latter $\left(R^{2}\right.$ linear $=0.5$; $p<0.001$ ), expressed as $\mu \mathrm{g} / \mathrm{L}$ (Fig. 3).

The median $\mathrm{B}-\mathrm{Hb}$ rose after end of exposure, from a median of 108 (range 92-139) g/L (Table 1) at the time of the first blood sampling to $138(122-155) \mathrm{g} / \mathrm{L}$ at end of

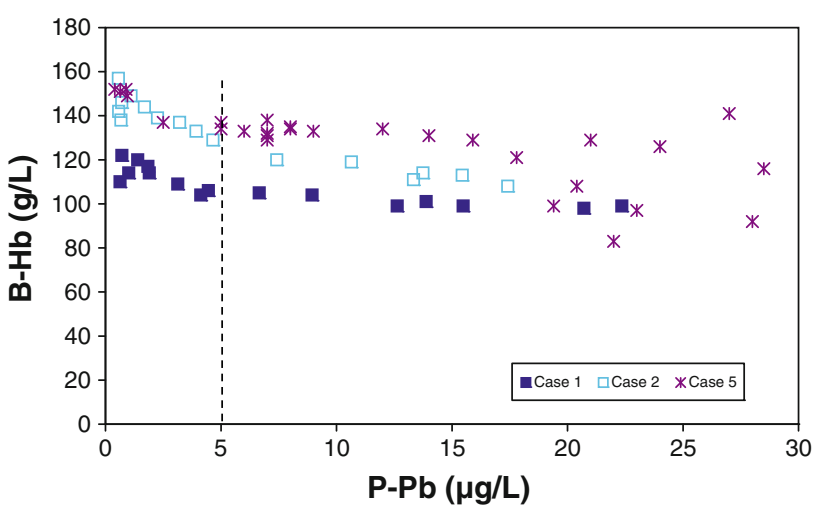

Fig. 4 Relationship between haemoglobin levels in blood (B-Hb) and lead in plasma $(\mathrm{P}-\mathrm{Pb})$ in sequential samples from three cases of poisoning

follow-up (not in table). In all patients, B-Hb values recovered to a stable level for each individual within a median time of 176 (range 145-230) days.

In three cases, there was sufficient information for a meaningful study of the relationship between $\mathrm{B}-\mathrm{Hb}$ and $\mathrm{P}-\mathrm{Pb}$ (Fig. 4). The association seemed to have two components, an initial fast increase at relatively low $\mathrm{P}-\mathrm{Pbs}$, and a slower one at high ones (all Ps for pairs of regression lines $\leq 0.01)$. The threshold $\mathrm{P}-\mathrm{Pb}$ between the two components was calculated at 4.3, 6.6 and $5.0 \mu \mathrm{g} / \mathrm{L}$, in Cases 1 , 2 and 5 , respectively.

Case 5, who was the only heterozygote for $A L A D$ G379C (earlier denoted as $A L A D$ 1-2; Table 1), had the longest $T_{1 / 2}$ for $\mathrm{B}-\mathrm{Pb}$, as compared to the others, who were homozygotes for the more common G-allele, while he did not differ from the others in $\mathrm{P}-\mathrm{Pb}$ kinetics (Table 2). Also, he had higher initial both $\mathrm{B}-\mathrm{Pb}$ and $\mathrm{P}-\mathrm{Pb}$ (Fig. 1), and a higher $\mathrm{B}-\mathrm{Pb} / \mathrm{P}-\mathrm{Pb}$ ratio (Fig. 2).

\section{Discussion}

The most important finding was that $\mathrm{P}-\mathrm{Pb}$ at poisoning was about $20 \mu \mathrm{g} / \mathrm{L}$. Biological half-time of $\mathrm{P}-\mathrm{Pb}$ was about 
1 month; decay in $\mathrm{B}-\mathrm{Pb}$ was much slower. $\mathrm{P}-\mathrm{Pb}$ displayed a non-linear relationship with $\mathrm{B}-\mathrm{Pb}$, but rectilinear with $\mathrm{U}-\mathrm{Pb}$.

The number of cases was small; in particular, we had only three cases with valid information on long-term B-Hb, which must be taken into consideration when drawing conclusions.

Since $\mathrm{Pb}$ content in red blood cells is much higher than in plasma, there is a risk that even a rather limited haemolysis, which may occur because of the haemolytic tendency at high $\mathrm{Pb}$ exposure, may contaminate the $\mathrm{P}-\mathrm{Pb}$. We eliminated the few plasma samples with haemolysis. A very slight red colour occurs before there is a serious problem of $\mathrm{Pb}$ carryover.

The present determination of $\mathrm{P}-\mathrm{Pb}$ by ICP-MS was accurate. However, there is still uncertainty, which is reflected in the large confidence intervals in the estimates of kinetic parameters for $\mathrm{P}-\mathrm{Pb}$, which is wider than for $\mathrm{B}-\mathrm{Pb}$. In particular, Case 5 was studied before development of that method. Hence, ETA-AAS was used for $\mathrm{P}-\mathrm{Pb}$ analyses, which was less sensitive. This is also obvious from the much greater variation of his data points in the elimination and $\mathrm{B}-\mathrm{Pb} / \mathrm{P}-\mathrm{Pb}, \mathrm{U}-\mathrm{Pb} / \mathrm{P}-\mathrm{Pb}$ and $\mathrm{B}-\mathrm{Hb} / \mathrm{P}-\mathrm{Pb}$ curves. This also explains why his first and third measurements are higher than the modelled $C_{1}+C_{2}$. However, it is most unlikely that the analytical method explains his higher $\mathrm{P}-\mathrm{Pbs}$ in general, which are more likely due to his greater skeletal $\mathrm{Pb}$ pool.

The elimination of $\mathrm{Pb}$ from both plasma and whole blood displayed at least two phases. The fast one reflects the soft tissues, the slow one the skeleton (Schütz et al. 1987; Nilsson et al. 1991). In spite of the long follow-up times, they did still not allow accurate estimates of the slow phase. Thus, we choose to use the better value obtained in our earlier study. The present $\mathrm{P}-\mathrm{Pbs}$ are much higher than those in Swedes with no particular exposure $(0.1-0.3 \mu \mathrm{g} / \mathrm{L}$ (Schütz et al. 1996; Bergdahl et al. 1999), and remained so long after end of exposure. Therefore, we did not subtract a level in Swedish subjects without excessive exposure.

The method for determination of $\mathrm{P}-\mathrm{Pb}$ with ICP-MS has been further developed. Hence, at our laboratory, the limit of detection is now $0.02 \mu \mathrm{g} / \mathrm{L}$ and the precision $6 \%$. Hence, it is possible to use $\mathrm{P}-\mathrm{Pb}$ as a biomarker in environmental health.

The number of cases is small, in particular we had only three cases with valid information on long-term B-Hb, which must be taken into consideration when drawing conclusions. In addition, the time of exposure and the total amount of $\mathrm{Pb}$ absorbed varied between the individuals; in particular, Case 5 differed. Hence, the body burden (mainly the skeletal content) of $\mathrm{Pb}$ differed, which will affect the elimination pattern after end of exposure (Nilsson et al. 1991). This was accounted for by the use of a twocomponent elimination model on an individual basis.
The relationship between the initial levels of the two components will vary depending upon the bone pool versus recent exposure. The pattern of $\mathrm{P}-\mathrm{Pb}$ fits better with exposure data than $\mathrm{B}-\mathrm{Pb}$, which may be because it better reflects uptake and body burden, especially at these high uptakes. Only after careful comparison of the patterns did we merge the information into combined conclusions.

The $T_{1 / 2}$ for $\mathrm{P}-\mathrm{Pb}$ of about 1 month is much longer than that reported after intravenous injection of $\mathrm{Pb}$ salt (Campbell et al. 1984).

The present $T_{1 / 2}$ s for $\mathrm{B}-\mathrm{Pb}$ are longer than previously reported (Schütz and Skerfving 1976; Rabinowitz et al. 1976; Schütz et al. 1987). This is certainly because the present cases had B-Pbs much higher than in the earlier studies. Thus, our subjects initially had anaemia, with an attenuation of the rate of $\mathrm{B}-\mathrm{Pb}$ decline when the effect on the blood cell formation and survival decreases as the body burden decays. Further - and more important - the curvilinear relationship between $\mathrm{B}-\mathrm{Pb}$ and $\mathrm{P}-\mathrm{Pb}$, at the initial decrease of the body burden, will not be reflected in a simultaneous decay of $\mathrm{B}-\mathrm{Pb}$. Hence, our $T_{1 / 2} \mathrm{~S}$ of $\mathrm{B}-\mathrm{Pbs}$ are fully compatible with both the earlier reports on $\mathrm{B}-\mathrm{Pb}$ and our $T_{1 / 2} \mathrm{~S}$ for $\mathrm{P}-\mathrm{Pb}$. Also, the non-linear $\mathrm{B}-\mathrm{Pb} / \mathrm{P}-\mathrm{Pb}$ relationship means that the $\mathrm{B}-\mathrm{Pb} / \mathrm{P}-\mathrm{Pb}$ ratio will differ between individuals and over time.

In spite of the time to diagnosis being long in some of the cases, the modelling resulted in estimates of both the $\mathrm{B}-\mathrm{Pb}$ and the $\mathrm{P}-\mathrm{Pb}$ content at $t=0$, which marked the actual end of exposure.

Poisoning with gastrointestinal, neurological and haematological symptoms and signs occurred at $\mathrm{P}-\mathrm{Pbs}$ of about $20 \mu \mathrm{g} / \mathrm{L}$ as indicated by extrapolation of the $\mathrm{P}-\mathrm{Pb}$ curves. In one of the cases (no. 4), the $\mathrm{P}-\mathrm{Pb}$ at diagnosis was much lower. However, we are less certain of the relevance, since the symptoms and signs were less convincing for intoxication.

The present data clearly show the well-known anaemic effect of $\mathrm{Pb}$ exposure (Bergdahl et al. 2006). Previous authors have described the relationship between exposure and $\mathrm{B}-\mathrm{Hb}$ by use of $\mathrm{B}-\mathrm{Pb}$ as a biomarker (Gennart et al. 1992). However, this may lead to spurious results, because the effect causes a decrease of the assumed indicator of exposure/risk, caused by the anaemia-induced decrease of binding possibilities for $\mathrm{Pb}$ in blood, and the saturation of binding sites. Our data clearly show the usefulness of $\mathrm{P}-\mathrm{Pb}$ as an indicator of the risk of haematological effects. The shape of the $\mathrm{B}-\mathrm{Hb} / \mathrm{P}-\mathrm{Pb}$ seemed to have at least two components. This is probably because, as said above, $\mathrm{Pb}$ has several different modes of action: inhibition of haem synthesis, inhibition of nucleotide synthesis and haemolysis. The present data does not allow allocation of these mechanisms to the $\mathrm{B}-\mathrm{Hb} / \mathrm{P}-\mathrm{Pb}$ curve, but it is obvious that there is a dramatic effect at a $\mathrm{P}-\mathrm{Pb}$ of about $5 \mu \mathrm{g} / \mathrm{L}$. 
Interestingly, Case 5, who was the only heterozygote for $A L A D \mathrm{G} 379 \mathrm{C}$, had the longest $T_{1 / 2}$ for $\mathrm{B}-\mathrm{Pb}$, as compared to the others, who were homozygote for the C-allele, while he did not differ from the others in $\mathrm{P}-\mathrm{Pb}$ kinetics. Also, he had a higher $\mathrm{B}-\mathrm{Pb} / \mathrm{P}-\mathrm{Pb}$ ratio and higher initial $\mathrm{B}-\mathrm{Pb}$, which is in accordance with earlier findings (Bergdahl et al. 1997; Fleming et al. 1998; Schwartz et al. 2000; Montenegro et al. 2006). However, the high $\mathrm{B}-\mathrm{Pb}$ observed may be due to a higher exposure, compared to the other cases.

\section{Conclusions}

The present $\mathrm{B}-\mathrm{Pbs}$ at onset of poisoning are high, well above occupational and other biological exposure limits (Skerfving and Bergdahl 2007). However, the present results are still relevant for evaluation of cases of poisoning. It is then important to consider that $\mathrm{B}-\mathrm{Pb}$, despite being one of the most used toxicological biomarkers all kind, has serious limitations because of the saturation at high exposure. Then, $\mathrm{P}-\mathrm{Pb}$ is a more adequate biomarker of $\mathrm{Pb}$ exposure and risk than $\mathrm{B}-\mathrm{Pb}$, which is in accordance with a closer association between $\mathrm{P}-\mathrm{Pb}$ and markers of haem synthesis, as compared to $\mathrm{B}-\mathrm{Pb}$, especially at high exposure (Hirata et al. 1995). $\mathrm{P}-\mathrm{Pb}$ at severe poisoning was about $20 \mu \mathrm{g} / \mathrm{L}$. Biological half-time of $\mathrm{P}-\mathrm{Pb}$ was about 1 month; whole blood decay was much slower. The ALAD genotype seemed to modify the toxicokinetics (higher level and slower elimination in whole blood), though only one of our cases was a heterozygote.

Acknowledgments The authors thank Ms. Anna Akantis for skilful technical assistance, Dr. Anna Oudin, Dr Med Sci and Dr. Ulf Strömberg $\mathrm{PhD}$ for statistical advice. This work was supported by the European Union (PHIME, contract no FOOD-CT-2006-016253). This publication reflects only the author's views; the European Community is not liable for any use that may be made of the information contained therein. Further, the work was supported by the Swedish Council for Working Life and Social Research (METALUND project), the County Councils of Southern Sweden and the Medical Faculty, Lund University.

Conflicts of interest The authors report no conflicts of interest. The authors alone are responsible for the content and writing of the paper.

Open Access This article is distributed under the terms of the Creative Commons Attribution Noncommercial License which permits any noncommercial use, distribution, and reproduction in any medium, provided the original author(s) and source are credited.

\section{References}

Barany E, Bergdahl IA, Bratteby LE, Lundh T, Samuelson G, Schütz A, Skerfving S, Oskarsson A (2002) Relationships between trace element concentrations in human blood and serum. Toxicol Lett 134:177-184
Bergdahl IA, Gerhardsson L, Schütz A, Desnick RJ, Wetmur JG, Skerfving S (1997) Delta-aminolevulinic acid dehydratase polymorphism: influence on lead levels and kidney function in humans. Arch Environ Health 52:91-96

Bergdahl IA, Vahter M, Counter SA, Schütz A, Buchanan LH, Ortega F, Laurell G, Skerfving S (1999) Lead in plasma and whole blood from lead-exposed children. Environ Res 80:25-33

Bergdahl IA, Gerhardsson L, Liljelind IE, Nilsson L, Skerfving S (2006) Plasma-lead concentration: investigations into its usefulness for biological monitoring of occupational lead exposure. Am J Ind Med 49:93-101

Campbell BC, Meredith PA, Moore MR, Watson WS (1984) Kinetics of lead following intravenous administration in man. Toxicol Lett 21:231-235

Costa de Almeida GR, de Freitas Tavares CF, de Souza AM, Sampaio de Sousa T, Rodrigues Funayama CA, Barbosa F Jr, TanusSantos JE, Gerlach RF (2010) Whole blood, serum, and saliva lead concentrations in 6- to 8-year-old children. Sci Total Environ 408:1551-1556

Fleming DE, Chettle DR, Wetmur JG, Desnick RJ, Robin JP, Boulay D, Richard NS, Gordon CL, Webber CE (1998) Effect of the delta-aminolevulinate dehydratase polymorphism on the accumulation of lead in bone and blood in lead smelter workers. Environ Res 77:49-61

Gennart JP, Bernard A, Lauwerys R (1992) Assessment of thyroid, testes, kidney and autonomic nervous system function in leadexposed workers. Int Arch Occup Environ Health 64:49-57

Hirata M, Yoshida T, Miyajima K, Kosaka H, Tabuchi T (1995) Correlation between lead in plasma and other indicators of lead exposure among lead-exposed workers. Int Arch Occup Environ Health 68(1):58-63

Montenegro MF, Barbosa F Jr, Sandrim VC, Gerlach RF, TanusSantos JE (2006) A polymorphism in the delta-aminolevulinic acid dehydratase gene modifies plasma/whole blood lead ratio. Arch Toxicol 80:394-398

Nilsson U, Attewell R, Christoffersson JO, Schütz A, Ahlgren L, Skerfving S, Mattsson S (1991) Kinetics of lead in bone and blood after end of occupational exposure. Pharmacol Toxicol 68:477-484

Rabinowitz MB, Wetherill GW, Kopple JD (1976) Kinetic analysis of lead metabolism in healthy humans. J Clin Invest 58:260-270

Schütz A, Skerfving S (1976) Effect of a short, heavy exposure to lead dust upon blood lead level, erythrocyte delta-aminolevulinic acid dehydratase activity and urinary excretion of lead deltaaminolevulinic acid coproporphyrin. Results of a 6-month follow-up of two male subjects. Scand J Work Environ Health 2:176-184

Schütz A, Skerfving S, Ranstam J, Christoffersson JO (1987) Kinetics of lead in blood after the end of occupational exposure. Scand J Work Environ Health 13:221-231

Schütz A, Bergdahl IA, Ekholm A, Skerfving S (1996) Measurement by ICP-MS of lead in plasma and whole blood of lead workers and controls. Occup Environ Med 53(11):736-740

Schwartz BS, Lee BK, Lee GS, Stewart WF, Simon D, Kelsey K, Todd AC (2000) Associations of blood lead, dimercaptosuccinic acid-chelatable lead, and tibia lead with polymorphisms in the vitamin D receptor and [delta]-aminolevulinic acid dehydratase genes. Environ Health Perspect 108:949-954

Skerfving S, Bergdahl IA (2007) Lead. In: Nordberg GF, Fowler BA, Nordberg M, Friberg LT (eds) Handbook on the toxicology of metals, 3rd edn. Academic Press, London, pp 599-643

Strömberg U, Lundh T, Skerfving S (2008) Yearly measurements of blood lead in Swedish children since 1978: the declining trend continues in the petrol-lead-free period 1995-2007. Environ Res 107:332-335 